\title{
On Speech Acts
}

\author{
I Dewa Putu Wijana \\ Universitas Gadjah Mada \\ E-mail: putu.wijana@ugm.ac.id \\ DOI: https://doi.org/10.18326/jopr.v3i1.14-27
}

Copyright (C) The Author (s)

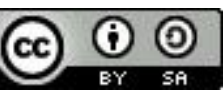

This work is licensed under a Creative Commons Attribution-ShareAlike 4.0 International License.

How to Cite: Wijana, I. (2021). On Speech Acts. Journal of Pragmatics Research, 3(1). doi: https://doi.org/10.18326/jopr.v3i1.14-27

\section{SUBMISSION TRACK: \\ Received: 18-01-2021 \\ Final Revision: \\ 05-03-2021 \\ Available online: \\ 01-04-2021 \\ Corresponding \\ Author:}

I Dewa Putu Wijana putu.wijana@ugm.ac.id

\begin{abstract}
This paper is intended to give insights to the readers about development of speech act theories which include categories, characteristics, validities, and strategies. The research begins with the classification of speech acts done by some experts and continues with description of characteristics and validities carried out especially by Austin and Searle, and ends with speech act strategies developed by Parker and Riley, using examples taken from Indonesian, Javanese, Balinese, and English, four languages that the writer masters relatively well. Most of Indonesian, Balinese, and Javanese data together with their context are created intuitively as a native or nearly-native speaker while some English utterances are created and the others extracted from pragmatic text books used as references in this study. Research findings show that there are various types of speech acts, and each speech act has its own validity conditions. Among them, illocutionary acts constitute the focal point of pragmatics' studies. The description shows that every expert of pragmatics uses different categories in classifying illocutionary acts, and the kinds of strategies used to express them. Keywords: pragmatics, speech act, speech act strategy.
\end{abstract}

\section{INTRODUCTION}

A speech act is any kind of act possibly done by a speaker in expressing an utterance. There are at least three kinds of acts, i.e. locutionary, illocutionary and perlocutionary acts. The first concerns with the act of saying something, the second with the act of doing something, and the last with the act of affecting someone. In pragmatics, the kinds of acts performed by the speaker are determined by contexts of utterance, which include speech participants, spatiotemporal setting of 
the utterance, and the intentions underlying the interlocution. Accordingly, one utterance can be used to express different speech acts. For examples, Indonesian utterance Handuk saya di mana? 'Where is my towel?' can be used to perform a speech act of questioning in a situation where the speaker wants to know where he has dropped the towel. And, it can also be used to perform a directive speech act with the intention to indirectly ask someone to bring him the towel because he wants to take a bath.

On the other hand, various kinds of utterances can be used to perform the same speech acts. For instance, utterances like $A k u$ sibuk 'I am busy', Aku banyak PR 'I have a lot of homework', Pamanku akan datang 'My uncle will come', Aku Lelah sekali 'I am very tired', etc. can be used to perform an act of refusal.

This paper is motivated by the increased number of students in the department of linguistics who wishes to write working papers, theses, even doctoral theses by choosing the area of pragmatics as their study objects. However, their knowledge about speech acts is still very superficial. In fact, speech acts constitute one of the profound aspects or topics discussed in this study area. In other words, it is absolutely impossible to study pragmatics without having an adequate knowledge about speech acts. The problem is getting more complicated because every linguist has different insights about speech act matters mainly concerning its category, classification, and strategy. Accordingly, this paper wants to briefly discuss about this matter using cases or examples found in four languages the writer adequately and sufficiently masters, i.e. Indonesian, Balinese, and Javanese, and English through instances exemplified by the text books used as references. The discussion will focus on three main aspects: speech act category, speech act classification, and speech act strategy. This study will hopefully complete the speech act studies that have been carried out by several scholars so far, such as a research done by Tutuarima et al. (2018: 122-131) concerning the way speech acts are expressed, their classification and the dominance of directive and expressive speech acts found in the movie entitled "London Has Fallen". Basra \& Thoyyibah (2017: 73-81) conducted a research on the classification of speech acts used by EFL (English as a Foreign Language) teachers and recommended the use of directive speech acts dominantly among any other ones in foreign language teaching activities. Praditya et al. (2014: 1-10) investigated the use of speech act categories found in the conversations between Habibie and Ainun in the film entitled Habibie and Ainun (2012).

Without any clear reason, the research finding shows that the use of representative speech acts is the highest in number compared to the other categories. Focusing on research seminar 
interlocution, Kamariah (2017: 145-178) found the questioning and answering acts as the dominant category in such type of occasion. Syah et al. (2017: 300-315) concentrated their study on the use of various directive speech act subcategories and their strategies found in one of TV One's talk show program "Satu Jam Lebih Dekat". The study is able to reveal many kinds of directive speech act subcategories, such as pleasing, requesting, asking, etc., and the strategies used to perform the acts covering bald on record, positive and negative, and bald off record as well.

Traditionally, language, the human verbal means of communication, is used by the speaker to say something in order to make the other person or individuals understand what they intend to communicate. However, in the more contemporary linguistic theories, new insights about language use have developed. Scholars nowadays view that a language is not merely used for saying or communicating something but can also be elaborated for doing something or affecting someone. All of these three aspects are respectively labelled locution, illocution, and perlocution, and consequently, there are three types of acts, i.e. locutionary act, illocutionary act, and perlocutionary act (Parker, 1986; Austin, 1962) that might exist in any verbal locution. The intention (external meaning) delivered through locutionary act is the easiest to identify, one through illocutionary act is more difficult, and one through perlocutionary is the most difficult. Nonetheless, in the development of speech act theory, all languages' linguistic uses are intended to perform different acts in different speech situations (Parker and Riley, 2012, 32) in which stating and asserting are included in one type of illocutionary acts.

In pragmatic theory, one kind of speech act can be performed by various types of utterances and contrarily one type of utterance can be used to express many kinds of speech acts. For example, in Indonesian, a speaker with the intention of asking someone to bring a drink can utter Saya haus sekali 'I am really thirsty'; Tolong, aku dibawakan minuman 'Help me, to bring me a drink'; Wah, saya lelah sekali sampai berkeringat jalan $10 \mathrm{~km}$ 'Oh, I am very tired, my body is sweaty after having walked for 10 kilometres'; Kowe isa njupukke aku wedang 'Could you bring me a drink'; etc. Meanwhile, the Indonesian utterance Saya mengantuk 'I am sleepy', depending on its contextual situation, can be used to mean 'I will go to have some sleep', 'You may go home now', 'I want you to make me a glass of coffee', 'We'd better stop the discussion now', etc. This fact indicates that the physically identical utterances may get different responses because of various speech acts they may deliver in any verbal interaction. For example, the Javanese utterance Iki jam piro? 'What time is it? can be answered 'It is seven o'clock' if it is uttered by someone who needs information about time. It can also be responded by Ya, aku tak mangan dhisik 'Yes Mum, but I would have my breakfast first' in the context of a mother asking her son to go to school but the son has not had his breakfast yet. Or, it is answered with $Y a$ 'yes' or 
does not get any response if it is uttered by a boarding house owner to a boy who, until too late at night, was still visiting his girlfriend.

Therefore, based on the discontinuities of the speaker's utterance and the utterance used to respond to the person whom they speak with, there are indications that interlocutor's speech is pragmatically underlined by various cultural assumptions shared by them. These facts show that pragmatic studies play an important role in order to comprehend better verbal human interactions. Pragmatic studies allow people to interpret what speakers mean in a particular context, and how the context influences what is said.

This study also helps to understand how listeners can make inferences from what is said in order to arrive at an interpretation of the speaker's intended meaning (Yule, 1996: 3). As far as the inferences are concerned, they must involve the ability of the speakers to identify what kind of speech act the speaker utters or intend to imply in every interlocution, or what kind of act the interlocutor performs in every utterance delivered in a given interaction.

\section{RESEARCH METHOD}

Utterances exemplified in this paper are obtained from various languages. Indonesian examples are created intuitively from my ability to use this language as my native and national language which I use in various occasions, mainly in formal situations or in communicating with ones who do not master Javanese and Balinese in informal speech situations. As a native speaker of Indonesian, I actively master this language both written and oral, and I am able to produces unlimited utterances. Based on this proficiency, the Indonesian data together with its contextual usage are intuitively created. The same procedure is carried out in creating Balinese utterances while the Javanese data collecting procedure is slightly different. The grammaticality of Javanese created data are first tested empirically with some Javanese speakers. Some of English utterances are created intuitively with the help of English Dictionary (Hornby, 2015) and Indonesian-English Dictionary (Echols and Shadily, 2003), and the others are taken from pragmatic and sociolinguistics text books used as references. To identify what kind of speech act the utterances perform, they are analyzed using contextual methods by perceiving the addresser and addressee, spatiotemporal setting of the interlocution, and other possible speech situations. All data are presented in orthographical transcription. 


\section{RESULTS \& DISCUSSION}

The following sections will respectively discuss more detail about various kinds of speech category, their linguistic characteristics and validity conditions, and strategies used to deliver.

\section{Speech Act Category}

Speech act concerns with any kind of act possibly performed by language speaker when delivering utterance. With regard to its category, it can be classified on the basis of two criteria, i.e. focus and function of speech act. These two criteria will be described in the following sections.

\section{Speech Act Classification Based on Focus}

Speech act can be differentiated based on its focus into three types. If a speech act is focused on the utterance delivered by the its speaker, it is called locutionary act (the act of saying something). In this matter, the act performed is identical with the meaning and mode of the utterance used to express. Consider for example the following Balinese sentences: Da jemaka pipis tiyange! 'Do not take my money', Nyen nyemak pipis tiyange 'Who took my money', Ake sing nyemak pis caine 'I did not take your money', etc. For expressing locutionary acts, these sentences are respectively used to say command, i.e. to forbid someone from taking the speaker's money; to ask someone for seeking information about anybody who has taken his money; to inform the addressee that he did not take the addresser's money. These three utterances have the same intentions with the modes of the sentence used to express, and the meaning of lexical items used to construct the utterances have the same meaning with what the speaker intends to. Therefore, locutionary acts have the least pragmatic impact in the interlocutions.

Unlike locutionary act, illocutionary one is focused on the kinds of act possibly performed by the speaker of an utterance (the act of doing something). The acts being performed contextually depend on various external factors, such as who the speaker are talking to, where, when, and to what end. As such, the Balinese utterance like Ken pipis tiyange? 'where is my money' in different context of situations is doing various actions, such as questioning, asking the addressee to return the debt or loan, asking the addressee to give him a money, etc. Based on the assumption that every conversation is built by cooperative principles between the interlocutors, when the question Ken pipis tiyange? is uttered to someone borrowing the speakers' money, the illocutionary force is not questioning but, instead, directing the addressee to return the money he had borrowed. However, if this utterance is expressed to his parents who have saved the money, the illocutionary act of questioning seems more appropriate.

Finally, perlocutionary act is a speech act intended to affect anyone. An Indonesian utterance like Ayah Ani di rumah 'Ani's father is at home' might be used by the speaker to affect the interlocutor for delaying his intention to visit his girl friend. In spite of the intention to inform 
the product being advertised, the Indonesian utterance of a beauty soap "Lux" Sabun Kecantikan Bintang-Bintang Film 'The soap of movie stars', might also simultaneously be used to affect the addressees' attitude for purchasing the product.

\section{Illocutionary Act as the Centre of Pragmatic Study}

As mentioned above, utterances containing locutionary acts that deliver intentions which are identical to the forms and meanings the linguistic constructions used to express. Therefore, such kinds of utterance have no or very little significance to the pragmatic problems. On the other hand, perlocutionary acts are still very difficult to study for what the speakers want to affect, and how the utterances influence the interlocutors are not easy to identify. These facts bring consequence that, up till now, illocutionary acts and everything related to them are still becoming the focus of attention of pragmatic studies. The different categories of illocutionary act are based on communicative functions of the utterance. In illocutionary perspectives, every utterance contains pragmatic forces which enable the addressees to infer what the speaker is directly, explicitly, as well as implicatively doing through its utterance, instead of just saying something.

With regard to illocutionary act, every expert has different taxonomies in classifying its category. Austin (1962, 150-163) differentiates verdictives, exercitives, commissives, and behabitives, and expositives (see also Wardhaugh, 1986, 276-277). Verdictives are specifically used for giving of a verdict, estimate, grade, or appraisal. Exercitives are typified for exercising of powers, rights, or influences, such as found in appointing, ordering, warning, or advising. Commissives are typically used for promising, and committing one to do something. Behabitives are acts commonly used for apologizing, congratulating blessing, cursing, or challenging. Finally, expositives are ones exploited for making utterances fit into an argument or exposition.

Meanwhile, Kreidler (1998, 176-194) classifies speech act into: assertive, performative, verdictive, expressive, directive, and phatic (see also Wijana, 2010, 94-99). Assertive speech act is an illocutionary act used to tell what the speakers know or believe whose mainly function is to inform, such as I say that I voted for Aaronson in the last election, We declare that most plastics are made from soy beans, etc. Performatives are ones used to bring about the state of affairs they name. These speech acts are considered valid if spoken by appropriate people to perform the acts. For example, the act of marrying, I pronounce you husband and wife is only valid if it is uttered by a catholic priest or other people of having right to do so. Verdictives are speech acts functioned to make judgment about the acts of the addressee, such as ranking, assessing, appraising, condoning, 
Wijana I.

etc, for example I thank you of helping me with the home work; I congratulate you for the highest mark in the general linguistic exam, etc. Expressive utterances are ones exploited by the speakers to make assessments of the acts of themselves, for example I acknowledge that I did not do what I should have done.

Whereas the verdictives involve what the addressees have done, the expressive acts do what the speakers feel. Directive utterances are those intended the addressees to perform an act or to refrain it, for example I order you to bring the provision, Do not hesitate to consult your problems, etc. Commissive utterances are ones which commit the speaker to do the action expressed within them, such as Tomorrow I am coming on time, I will be there, etc. At last, phatic utterances are those used by the speakers to establish rapport between the same community members, such as How are you, Nice to meet you, etc.

Finally, speech act taxonomy proposed by Searle (1976) consists of 6 types of illocutions. Those are representative, directive, question, commissive, expressive, declaration (See Parker \& Riley, 2012). Representatives are utterances used to describe state of affairs, such as the following Indonesian utterances Dia memiliki 5 buah rumah 'He has five houses', Made berasal dari Bali 'Made is from Bali', etc. This category includes the acts of stating and asserting, such as Bali consists of 8 regencies; denying, such as Saya tidak mau pergi ke sana 'I do not like to go there'; confessing, such as Saya mengambil uang itu 'I stole the money'; admitting, such as Dia memang pandai 'He is really clever'; notifying, such as Listrik akan padam mulai pukul 10.00 s.d 12.00 'The electricity will be out from ten up to twelve'; concluding, such as Jadi, dia yang melakukan semuanya ini 'So, he did all of these'; predicting, such as Hari ini pasti hujan 'It will rain today'.

Directives are all types of utterance expressed to ask the addressees to do or to not do something held in the utterance. This illocution category includes requesting, such as expressed by the following Javanese utterances: Pak, tukokno aku es krim 'Dad, please buy ice cream for me', ordering, such as Sesuk bangun esuk-esuk 'Tomorrow, wake up early', forbidding, such as Ungsum rendeng ojo dolanan ning kali 'In rainy season, don't go to the river', warning, such as Nek prestasimu elek, tak ganti 'If your performance is bad, I would replace you', advising, such as Kowe kudu okeh istirahat 'You must take much rest', suggesting, such as Gawa bojomu ning Australia 'Take your wife to come along to Australia', insisting, Nganggo pendekatan ini nek pengin isa 'Use this approach if you want to be successful', recommending, such as Wacanen buku-buku pragmatik 'Read books on pragmatics', etc.

Questions are illocutionary acts intended for asking something to the addressees. This category includes asking, inquiring, etc. Javanese utterances such as Sopo kui 'Who is he?', Bojone saka ngendi? 'Where does his wife come from?', Aku pengin ngerti jenenge bojone 'I want to know what her husband name is', etc. seem fit to be categorized into this type. This 
category is included in directive by Searle related to the answer required by the speaker (see also Dardjowidjojo, 2003, 99-107).

Commissive acts are ones intended to commit to do something. Indonesian utterances such as Tunggu sebentar saya akan Kembali setengah jam lagi 'Please wait, I will be back in 30 minutes', Saya akan mengganti setiap barang yang pecah 'I will replace every broken goods', etc. This kind of act includes promising, vowing, offering, betting, pledging, and so on.

Expressive speech acts are found in utterances used to expressed emotional states of the speakers. Balinese sentence such as Tiyang ngidih pelih 'I beg your pardon', Tiyang ngaturang suksma 'I express my thanks', Selamat nggih 'Congratulation!', etc. This acts include apologizing, thanking, condoling, welcoming, etc.

Declarations are all utterances that are used by the speakers for changing the status of some entity, such as expressed by the following Indonesian expressions: Kamu keluar 'you are out' uttered by an umpire in soccer match, Akan saya baptis anak ini Dorothea 'I baptize this child Dorothea', Kamu saya tahan 'I arrest you'. This kind of speech act includes appointing, proclaiming, baptizing, surrendering, etc. Because of these disperse classifications, it is important for the researchers to consistently use one of them, or try to combine them to achieve a better or more comprehensive formula.

\section{Linguistic Characteristics and Validity of Speech Act}

Allan $(1986,10)$ states that speaking is a social activity. In this activity, anyone involved should mutually recognize that certain conventions govern their actions and their ways of using language, as well as their interpretation of the utterances that the speakers are talking to. Each participant is responsible for his/her all actions and language use and any kind of violation they made in language interchange. This communicative presumption clearly indicates that there are also certain conventions to be obeyed by speech participants in order for their utterances to be reasonably comprehended in every interlocution. As far as speech act is concerned, the utterances constructed should syntactically and pragmatically be characterized by the following criteria:

1. The subject must be filled by first person and the verb must be in the present tense, such as $I$ promise that I won't be late. Meanwhile, utterance like I promised that I would not be late does not constitute a performative utterance because it contains past tense verb 'promised'. The same rule applies to John promises that he won't be late that contains third person (John) 
subject. With regard to Indonesian, and most of local languages in Indonesia, even the utterance should express present or future action, the verbal form might be the same because tense matters are not grammatically constructed, yet lexically by adverb of time or it is just implied. So, the Indonesian utterance such as Saya akan membaca buku itu 'I will read that book' is a performative act, while Saya sudah membaca buku itu and Dia membaca buku itu are not, even though the verbal forms do not change. In addition, because of linguistic individuality of Indonesian, and several local languages in Indonesia in which different focus of Asian languages in one hand, and western languages on the other (Dardjowidjojo, 1986, 57-70), performative utterances can be expressed in passive voice, for example Indonesian sentence Akan saya ambil buku itu, Lakar kajemak bukune ento, Arep tak jupuk buku kui which all mean 'I will take that book'. These passive sentences seem more appropriate to perform speech act than their active equivalents.

2. Besides the syntactic characteristics outlined above, in order to be considered valid or felicitous, utterances expressing performative actions should have the following sincerity and felicity conditions:

a. The person and circumstances must be appropriate. For example, in order to be valid, the following Indonesian sentences Kamu keluar 'you are out', Akan saya nikahkan saudara dengan putri saya 'I will marry you with my daugther', Dengan resmi pertemuan ini saya nyatakan dibuka 'I declare that the meeting is officially opened' must take place respectively in football match, wedding ceremony, and conference or seminar by an umpire, daughter father, and university rector or faculty dean, etc.

b. All speech participants must have appropriate intentions. Without sincerity, the act of forgiving and apologizing expressed in the following Javanese utterances could be infelicitous: Ya kowe tak ngampura 'Yes I will forgive you', Sesuk aja kok baleni 'Please don not do that again', Aku njaluk ngapura, ya? 'I beg you pardon'.

c. The speakers must believe that they can perform the action. For example the Balinese utterance such as Yadyapin joh 10 kilo, tiyang lakar majalan kemu 'Although it is far about 10 kilos, I will go there by walking' will be a felicitous utterance if it is expressed by a normal individual. Otherwise, it will not be felicitous if it is expressed by a limp person. In Indonesian song lyrics, there are a lot of expressions like Gunung yang tinggi kan kudaki 'I will climb the high mountain', Laut yang luas akan kuseberangi 'I will cross the wide ocean', etc. These felicitous violations are intended to gain hyperbolic effects and intensify the depth of the speaker's love.

d. The speaker must predicate a future action. The action must be one the has not been executed, instead of one that has already done. The Javanese sentences Tak lunga ah, 'I 
will go (now)', Takenteni kowe neng kene 'I will wait for you here', etc are all predicating future actions. However, Aku wingi ngenteni kowe ning kene 'Yesterday I was waiting for you here' and Aku wis lunga menyang omahe 'I have been to his house' do not constitute performative acts because they do not predicate future actions but the past ones.

e. The speakers must predicate an act of themselves, instead of others. For example, the Indonesian utterance like Saya berjanji bahwa saya akan datang tepat waktu 'I promise that I will arrive on time', as long as it is expressed with sincere intention, constitutes a felicitous performative action because it predicates the speaker's action. However, Saya berjanji pasti dia akan datang tepat waktu 'I promise that he certainly will arrive on time' is not felicitous because it predicates the action of another person.

\section{Speech Act Strategy}

As part of rhetoric, either textual or interpersonal, pragmatics is essentially a branch of linguistics that concerns with the strategies available for the speakers to choose in different speech situations (Leech, 1983, 15). The choice of strategies is strongly influenced by various sociocultural factors and communicative intentions of the speakers to the person or people they are speaking with. Those factors can simply be measured based on three dimensional ratings, i.e. distance rating, power rating, and rank rating (Brown \& Levinson, 1978; Wijana 1996, 64-66). These three ratings are respectively determined by degree of intimacy, social and economy status of the speaker and the addressee, and emergency state of the speech act. Thus, the communicative competence the speakers have will determine which strategy they would choose in speaking with the intimates, the person of higher or lower status, as well as in conversing in formal or less formal situations. All these facts in turn will manifest various kinds of utterance with different politeness or degrees of formality representations. The various modes of utterances essentially reflect the strategy chosen by the speaker in different speech situations. The speech strategies can be classified into various categories based on several criteria. Those strategies are explicit and nonexplicit strategy, direct and indirect strategy, literal and nonliteral strategy, and expressed and implied strategy. All of these will be described as follow:

\section{Explicit and Nonexplicit Strategy}

In formal speech situation, explicit strategy is often found through Indonesian utterances like Saya menyatakan engkau bersalah 'I states that you are guilty', Saya mengakui bahwa soal 
itu memang sulit 'I admit that the problem is really difficult', etc. These two utterances explicitly show their performative verb, i.e. menyatakan 'to state' and mengakui 'to admit'. All of these utterances constitute explicit speech strategy. However, in less formal interactions, the first clauses are often deleted, and only the subclause uttered by the speakers, Engkau bersalah 'you are guilty' and Soal itu memang sulit 'the problem is really difficult'. The types of act represented by the formal and less formal style are the same, yet the strategies exploited are different, i.e. between explicit and nonexplicit strategy.

\section{Direct Strategy and Indirect Strategy}

Syntactically, mode of sentence can be differentiated into three categories, i.e. declarative, interrogative, and imperative. Declarative sentences are used by the speaker to declare or announce something to the addressee. Interrogative sentences are ones exploited by the speaker to ask or to seek information from the addressee. Meanwhile, imperative sentences are ones used by the speaker to order or command the addressee to do something. In case of directive utterances expressed using imperative sentence, the strategy used by the speaker is called direct strategy for there is a direct correspondence between the syntactic forms of the utterance and the kind of act wanted to be expressed by the speaker. For example, Silakan datang ke rumahku! 'Please come home' is a direct speech act if this sentence is used to invite the addressee. Apakah rumahmu di Solo? 'Is your house at Solo?' is also a direct act if it is used by the speaker to get information about the speaker's domicile. Aku punya beberapa rumah 'I have several houses' also constitutes a direct act if it is used by the speaker to give the addressee information about the number of house the speaker has.

For more polite speaking, the utterance Handukku di jemuran 'My towel is on the clothe line' and Di mana handukku 'Where is my towel' are exploited by the speaker to order or command the addressee. The speech act strategy chosen by the speaker belongs to indirect strategy for the sentence modes used to express are matched with the type of speech act the speaker intends to perform. According to Parker and Riley $(2012,38-39)$ utterance like And you are... is an indirect speech act strategy because the sentence is conventionally used to perform an act of questioning Who are you? . Yes-no question like Do you have time? is also considered to perform indirect illocutionary act because it is intended to represent another type of question (information question) What time is it?

\section{Literal and Nonliteral Strategy}

Generally speaking, utterances are commonly used to convey meanings in accordance with the literal meanings of the linguistic structure constructing them. For example, Javanese utterances 
Suaramu apik 'Your voice is beautiful', Pacarmu bagus 'your boy friend is handsome', and Gitaranmu luar biasa 'The way you play guitar is extraordinary', etc are delivered respectively to admire that the addressee has a beautiful voice, a good looking boyfriend, and an excellent guitar play. The speech strategy in which the literal meaning of the utterance is matched with the semantic intention the speaker wants to express is called direct strategy. In contrast, for communicating tease and insult, the speaker might also use the last three utterances above for bearing intentions which are totally opposed with their literal meaning. The illocutionary act strategy performed by the speaker is called Nonliteral strategy. Javanese speakers often use this kind of strategy in various speech acts, such as admiring, ordering, prohibiting, etc. This speech phenomenon in local term is called 'Ngelulu'.

\section{Expressed and Implied Strategy}

Another way to speak more politely to the addressee can be carried out by constructing utterances containing implicatures. In this matter, the speaker does not make direct prohibition, denial, command, order, request, etc., but constructing ones which can be inferred that the response given are bearing such intentions though implicatively. Thus, the Javanese response Ungsum udan, lho 'it is rainy season' is an implicative response of a mother in order to refuse her young boy request playing in the river. Rainy season implies flood that might endanger the child safety. So, this answer is an implied strategy used to deny the child's request. Ning kene polisine galak-galak 'In here the policemen are very strict' could be an implicative advice given to the addressee for always beware of obeying driving rules if $\mathrm{s} /$ he does not want to be caught because of traffic violations. So, utterances like Aja lunga ning kali 'Do not go to the river', or Aja melanggar aturan 'do not violate (traffic) regulation' are the expressed strategies for those Javanese implicative utterances.

\section{CONCLUSION}

Pragmatics is one of the most complicated branches of linguistics to study and one of the topics which has such characteristics as speech acts. In speech act, the types and categories are not solely determined by the expressed forms, but by the focus, function, and strategy as well. A certain intention can be expressed by different forms, and one form can be exploited to deliver various intentions. In other words, intentions or the speaker meanings do not have their root in linguistic structures even though structures are used as point of departure to every interpretation of 
intentions meant by the speakers. Because locution is regarded not important in pragmatics, and perlocution is also still very difficult to understand, illocution becomes the focus of attention of this study. As far as the illocutionary acts are concerned, the taxonomy of speech act existing in a language can be classified based on the functions and delivery strategies. The former will yield representative, directive, questioning, commissive, expressive, and declaration, while the later will result various strategies, i.e. explicit and nonexplicit, direct and indirect, literal and nonliteral, and expressed and implied. Finally, the development shows that speech act theories and all related issues tend to be more and more complicated in the future.

\section{REFERENCES}

Allan, Keith. (1986). Linguistic Meaning. Vol. 1. London: Routledge \& Keagan Paul.

Austin, J.L. (1962). How to Do Things with Words. Oxford: Clarendon Press.

Basra, Sri Meiweni \& Luthfiyattun Thoyyibah. (2017). "A Speech Act Analysis of A Teacher Talk in An EFL Class Room”. International Journal of Education. Vol. 10, No. 1. Bandung: Universitas Pendidikan Indonesia. Pp. 73-81.

Brown, P \& S. Levinson. (1978). "Universals in Language Usage: Politeness Phenomena". Questions and Politeness: Strategies in Social Interaction. E.N. Goody (Ed.). Cambridge: Cambridge University Press.

Dardjowidjojo, Soenjono. (1986). "Bentuk Pasif sebagai Cermin Pikiran Bangsa". Pusparagam Linguistik dan Pengajaran Bahasa. Bambang Kaswanti Purwo (Ed.). (pp. 57-70). Jakarta: Arcan.

Dardjowidjojo, Soenjono. (2003). Psikolinguistik. Jakarta: Obor.

Echols, John M. \& Hassan Shadily. Kamus Indonesia-Inggris. Jakarta: Gramedia Pustaka Utama. Hornby, A.S. (2015). Oxford Advanced Learner's Dictionary. Oxford University Press.

Kamariah, A. (2017). "Types of Speech Acts Used in Research Seminar". Elite: English and Literature Journal. Vol.1, No.1. Makassar: Alaudin State Islamic University.Pp. 145-178.

Kreidler, Charles W. (1998). Introducing English Semantics. London: Routledge.

Leech, Geoffrey. (1983). Principles of Pragmatics. London: Longman.

Parker, Frank. (1986). Linguistics for Non-Linguists. London: Francis and Taylor Ltd.

Parker, Frank \& Kathryn Riley. (2012). Linguistics for Non Linguists. Singapore: Pearson.

Praditya, I Made Dwi Jaya, I Nyoman Adi Jaya Putra \& Luh Putu Artini. (2014). “An Analysis of Speech Acts in The Conversations between Habibie and Ainun in The Film Entitled Habibie and Ainun 2012" . E-Journal Program Pascasarjana Universitas Pendidikan Ganesha. Vol. 2. Singaraja: Program Studi Bahasa Inggris Universitas Pendidikan Ganesha. Pp. 1-10. 
Journal of Pragmatics Research

Vol. 03, No. 01 (2021), pp.14-27

E-ISSN: $2656-8020$

Website: http://e-journal.iainsalatiga.ac.id/index.php/jopr/index

Searle. John, J.R. (1976). “The Classification of Illocutionary Acts”. Language in Society. (pp. 124). Cambridge University Press.

Syah, Nur Ainy, Sumarlam \& D. Djatmiko. (2017). "The Politeness of Directive Speech Acts in Satu Jam Lebih Dekat”: Pragmatic Approach”. Prasasti Journal of Linguistics. Vol. 2, No. 2. Surakarta: Program Studi S3 Linguistik Pasca Sarjana Universitas Sebelas Maret. Pp. 300315 .

Tutuarima, Zulva, Nuraeningsih \& Rusiana. (2018). “An Analysis of Speech Act Used in London Has Fallen Movie”.Vision: Journal for Language and Language Learning. Volume 7. No. 2. Semarang: UIN Walisongo. Pp. 122-131.

Yule, George. (1996). Pragmatics. H.G. Widdowson (Ed.). Oxford University Press.

Wardhaugh, Ronald. (1986). An Introduction to Sociolinguistics. Oxford: Basil Blackwell.

Wijana, I Dewa Putu. (1996). Dasar-dasar Pragmatik. Yogyakarta: Andi.

Wijana, I Dewa Putu. (2010). Pengantar Semantik Bahasa Indonesia. Yogyakarta: Pustaka Pelajar. 